political teleologies and eschatologies; or others that you might propose.

Applied Political Science.* Howard Silver, Consortium of Social Science Associations, Suite 836,1522 K

Street, Washington, DC 20005; (202) 842-3525.

Panels in this section should focus on how our political science training is applied in government at all levels, the non-profit sector including academia, and the for-profit sector. Interpret "applied political science" as broadly as you desire. Training of political scientists in the application of their knowledge can also be a focus. Applying political science in conjunction with other social and non-social sciences can also be the subject of panel proposals. Panels that used to be in the "political science as a profession" section would be welcome here.

Science and Technology Studies.* Gary Bryner, Department of Political Science, Brigham Young University, Provo, UT 84602; (801) 378-3276.

Science and Technology Studies is a relatively new organizing concept in political science that centers on the political implications of technological change and scientific advances. We welcome proposals for papers and panels that address science and technology from a variety of theoretical perspectives and empirical approaches. Illustrative of the kinds of questions we hope scholars will address are: (1) What are the central ideas and concerns of science and technology studies? What are the different ways of defining this area of study? What are the most fruitful theoretical or conceptual approaches to understanding the political significance of science and technology? (2) What are the most relevant characteristics of science and technology for political scientists? What are the ideas, theories, conceptual frameworks, and concepts from political science that can be usefully applied to science and technology studies? What kinds of issues that are central to science and technology studies help explore the major concerns of political science? (3) What are the social properties of science and technology? What social and political institutions are central to the role of science and technology in political, economic, and social systems? (4) What challenges do science and technology-related policies pose for policy making? What are the primary characteristics of these kinds of policies? How well do the institutions of government assess the consequences of scientific and technological changes and develop appropriate policy responses? How does policy making in this area contribute to our understanding of politics and government?

Computer Users.* G. David Garson, Department of Political Science and Public Administration, North Carolina State University, Raleigh, NC 27695-8102; (919) 737-2468 or 3067.

The Computer Users section of the American Political Science Association is soliciting proposals in the following areas: political and social impacts of information technology; innovative uses of new or existing software for research; innovative uses of new or existing software for instruction; innovative ways of integrating computer topics in political science courses; and interdisciplinary aspects of computing in the social sciences. Past topics have included survey research, statistical analysis, expert systems, policy analysis, organizational impacts, and computer-assisted instruction, all of which are seen as illustrative of continuing interests of the section. A limited number of proposals will be accepted for mini-workshop sessions in which a single topic will be presented in depth by a single presenter, with distribution of tutorial materials. One session is contemplated for persons interested in sharing experiences and views regarding social science computing, without formal presentations; interest in leading or participating in this discussion roundtable is solicited. Presentation formats other than traditional reading of papers are encouraged but not required. Please submit abstracts of proposed presentations along with information on your equipment requirements for the presentation, if any.
Political Communication.* G. R. Boynton, Department of Political Science, University of Iowa, Iowa City, Iowa 52242; (319) 335-2338. Bitnet: blabynpd@uiamvs.

Research on political communication has largely focused on the mass media and their audiences, campaigning in elections, and presidential communication with the citizenry. Papers and panel proposals on these subjects are welcomed. It seems clear that equally important communication is going on at other points in government and politics: conversations between citizens, in legislatures, in courts, in international relations, and many other sites. Proposals for papers and panels studying communication in these other locations are especially encouraged. In addition to encouraging diversity in the sites for studying political communication, the section wants to encourage diversity in the style of analysis employed-from rigorous rhetorical analysis to rigorous statistical analysis and any other technique that is appropriate for the research. Please include an abstract describing the proposed panel or paper with the request.
Editor's Note: The Policy Studies Organized Section had not identified their 1991 program organizer by the September PS deadline. Please pay close attention to future issues of PS for information regarding this section.

\section{APSA Research Grantees Announced}

The APSA Research Support Committee announced the 1990 Research Grantees on May 1. The Council established the research grant program in 1984, and authorized $\$ 15,000$ to be distributed annually. To be eligible for a grant the applicants must be APSA members and must either be a faculty member at a non-Ph.D. granting college or university or be a political scientist 
not affiliated with an academic institution. Funds are used for research that addresses a significant problem in political science.

The Selection Committee, composed of Gary Jacobson, University of California, San Diego, chair; Donna Bahry, University of California, Davis; David Brady, Stanford University; Roy F. Grow, Carleton College; Timothy Tilton, Indiana University; and Carole Uhlaner, University of California, Irvine, reviewed 32 applicants and made 11 awards. The grantees are:

Elizabeth W. Marvick, "Virginia's Founding Fathers as a Revolutionary Elite: Family Experience and Personality in Shaping the Institutions of the New Nation."

James W. McGuire, Wesleyan University, "Political and Economic Causes of Argentine Strikes, 19831989."

Donley T. Studlar, Oklahoma State University, "The Role of Minor Parties in the Political Recruitment of Women-The NDP in Canada."

Robert Dilger, University of the Redlands, "Residential Community Associations: Their Impact on American Governance."

John P. Burke, University of Vermont, "Coping with the Institutional Presidency: A Study of the White House Staff and Presidential Management Styles."

Gloria J. Braxton, Southern University, "Women, Power, and Influence in Liberia: Historical and Contemporary Perspectives."

Lee Ann Banaszak, Iowa State University, "The Swiss Women's Suffrage Movement, the State and Other Political Actors."

Patrick R. Ireland, Connecticut College, "Immigration in Western

Europe."

Huey L. Perry, Southern University, "Black Politics, Economic Development and Fiscal Policy Making in Two Southern Cities."'

Janna C. Merrick, St. Cloud State University, "Maternal-Fetal Rights: Adversaries or Allies?"

Alfredo Rehren, Universidad de Chile, "Executive Leadership and the
Redemocratization of Argentina, Chile and Uruguay."

\section{Ralph Bunche Summer Institute}

Twenty-five juniors who will be seniors this coming academic year were selected to participate in the fifth annual Ralph Bunche APSA Summer Institute in Political Science for Black Students, held June 11July 21 in Atlanta.

The Institute was conducted by a consortium consisting of Spelman College, Morehouse College, Georgia State University, and Emory University. Lois Moreland of Spelman was Director. Naomi Lynn of Georgia State, Tobe Johnson of Morehouse, and Eleanor Main and Micheal Giles of Emory were coordinators on their respective campuses.

The students selected as the winning participants came from diverse universities and colleges from 20 different states and the District of Columbia:

\section{Gayle Anderson, University of Portland}

Monique J. Bocock, University of Maryland, Baltimore County

Dorian L. Brown, Spelman College

Teresa J. Burl, University of

Arkansas, Little Rock

Dana M. Bush, Harvard University

Montrese M. Chandler, Howard

University

Daniella D. Daniel, Purdue

University

Ella M. Davis, University of North Alabama

Sherri Davis, Norfolk State

University

Doris M. Daye, North Carolina A\&T University

Stephen E. Hart, Oakland University

Kevin L. Hatcher, Grambling State University
Kimberly Henderson, Georgetown University

Tina F. Johnson, University of Alaska, Anchorage

Olivia A. Jones, Florida A\&M

University

Darrel T. King, Florida International University

Frances R. McNeal, University of Iowa

Barbara E. Rhodes, Mississippi College

Michael Ricks, Norfolk State University

Kimaria L. Seymour, University of Tennessee, Martin

James Smylie, Sangamon State University

Pamela M. Sutton, Washington University

LaTrice M. Washington, St. Augustine's College

Frank H. Williams, San Diego State University

Janell L. Wood, Western Kentucky University

Established in 1986, the Summer Institute is designed to encourage black students to pursue academic careers in political science. In prior years, the Institute was conducted in Baton Rouge, Louisiana by the Louisiana State University and Southern University.

The six-week program has five primary objectives:

- to introduce the participants to leading issues and problems in the discipline and profession of political science;

- to inform students of career opportunities for political scientists;

- to enhance the general academic skills of the participants, making them more competitive applicants for graduate school admission and financial assistance;

- to introduce students to quantitative and analytical methods of study in political science;

- to expose participants to leading scholars in the discipline. 